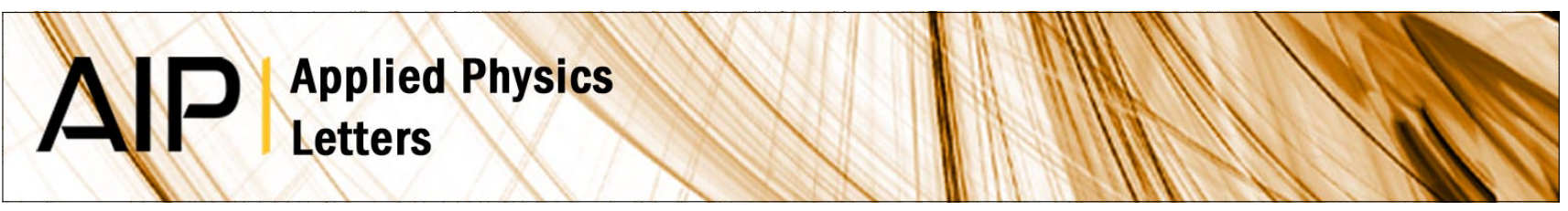

\title{
Comment on "Experimental evidence of thermonuclear neutrons in a modified plasma focus" [Appl. Phys. Lett. 98, 071501 (2011)]
}

M. M. Milanese

Citation: Appl. Phys. Lett. 100, 016101 (2012); doi: 10.1063/1.3674314

View online: http://dx.doi.org/10.1063/1.3674314

View Table of Contents: http://apl.aip.org/resource/1/APPLAB/v100/i1

Published by the American Institute of Physics.

\section{Related Articles}

Monoenergetic proton emission from nuclear reaction induced by high intensity laser-generated plasma Rev. Sci. Instrum. 83, 02B111 (2012)

Improved chopping of a lithium beam for plasma edge diagnostic at ASDEX Upgrade Rev. Sci. Instrum. 83, 023501 (2012)

Response to "Comment on 'Experimental evidence of thermonuclear neutrons in a modified plasma focus'" [Appl. Phys. Lett. 100, 016101 (2012)]

Appl. Phys. Lett. 100, 016102 (2012)

Mass spectrometric investigation of high-mass neutral species in the downstream region of $\mathrm{Ar} / \mathrm{CH} 4$ plasmas J. Appl. Phys. 110, 013304 (2011)

Application of tomographic particle image velocimetry to studies of transport in complex (dusty) plasma Phys. Plasmas 18, 050702 (2011)

\section{Additional information on Appl. Phys. Lett.}

Journal Homepage: http://apl.aip.org/

Journal Information: http://apl.aip.org/about/about_the_journal

Top downloads: http://apl.aip.org/features/most_downloaded

Information for Authors: http://apl.aip.org/authors

\section{ADVERTISEMENT}

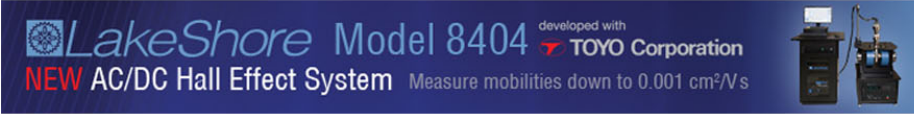




\title{
Comment on "Experimental evidence of thermonuclear neutrons in a modified plasma focus" [Appl. Phys. Lett. 98, 071501 (2011)]
}

\author{
M. M. Milanese $e^{a)}$ \\ Laboratorio de Física Arroyo Seco, Universidad Nacional del Centro de la Provincia de Buenos Aires and \\ CONICET, Pinto 399, 7000 Tandil, Argentina
}

(Received 27 October 2011; accepted 13 December 2011; published online 3 January 2012)

[doi:10.1063/1.3674314]

On page 3 of Ref. 1, the authors claim: "It is for the first time when the ion temperature of thermonuclear Z-pinch plasmas is calculated from the width of neutron energy spectrum." They are probably unaware of Ref. 2, in which one of the main results we reported were neutron spectra measurements made in the $1 \mathrm{MJ}$ plasma focus at Frascati. These spectra were obtained by the time-of-flight method, with a time-resolved detector placed at a distance of $140 \mathrm{~m}$ from the neutron source, therefore giving a very accurate

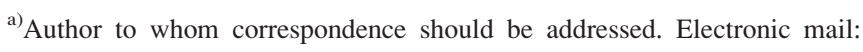
milanese@exa.unicen.edu.ar. spectral resolution. On page 535 of Ref. 2, several spectra are shown, where the width is signalised. From the results from many spectra, a temperature of deuterons was calculated from the formula $\Delta \mathrm{E}=82.5[\mathrm{kT}]^{1 / 2}$ as derived by Lehner and Pohl. ${ }^{3}$ In other words, back in the 1970s, the width of the neutron spectra was used, and the deuteron temperature at the Frascati's 1 MJ device was estimated.

${ }^{1}$ D. Klir, P. Kubes, M. Paduch, T. Pisarczyk, T. Chodukowski, M. Scholz, Z. Kalinowska, E. Zielinska, B. Bienkowska, J. Hitschfel et al., Appl. Phys. Lett. 98, 071501 (2011).

${ }^{2}$ M. M. Milanese and J. Pouzo, Nucl. Fusion 18, 533 (1978).

${ }^{3}$ G. Lehner and F. Pohl, Z. Phys. 207, 83 (1967). 